\title{
EKSTRAKSI SENYAWA FLAVONOID DARI DAUN KUNYIT (Curcuma Longa L) BERBANTU GELOMBANG MIKRO UNTUK PEMBUATAN BIOFORMALIN
}

\author{
Windi Arum Mukti", Suwardiyono dan Farikha Maharani \\ Jurusan Teknik Kimia, Fakultas Teknik, Universitas Wahid Hasyim \\ J1. Menoreh Tengah X/22, Sampangan, Semarang 50236 \\ *Email : Haiwindiarummukti@gmail.com
}

\begin{abstract}
Abstrak
Tanaman kunyit (Curcuma Longa L) merupakan tanaman yang sering dijumpai di Indonesia, namun pemanfaatan tanaman ini masih hanya sebatas rimpangnya saja, sedangkan bagian daunnya masih minim pemanfaatan padahal terkandung senyawa metabolit sekunder yang bermanfaat seperti flavonoid. Karakteristik flavonoid yang memiliki sifat antibakteri dapat digunakan sebagai bahan pengawet makanan alami atau bioformalin. Dengan menggunakan metode ekstraksi berbantu gelombang mikro, penelitian ini bertujuan untuk mengevaluasi pengaruh variabel daya, rasio umpan - pelarut, dan waktu ekstraksi, serta mencari nilai rendemen yang didapat dan untuk mengetahui waktu simpan optimum pada bakso ayam yang diberi bioformalin. Percobaan dilakukan dengan variabel daya 10\% hingga $30 \%$ daya maksimum alat (399 watt), variabel rasio umpan pelarut 1:10 hingga 1:30 dan dengan variabel waktu ekstraksi 10 hingga 30 menit. Dengan pengaplikasian pada bakso ayam dengan perendaman selama 2 jam dengan konsentrasi 1\% dan 2\%. Hasil percobaan menunjukkan ketiga variabel daya, rasio umpan - pelarut dan waktu ekstraksi berpengaruh terhadap konsentrasi flavonoid hasil ekstraksi. Secara umum, konsenstrasi flavonoid mengalami kenaikan seiring kenaikan ketiga variabel sampai maksimum di titik tertentu, kemudian turun. Konsentrasi maksimum diperoleh pada variabel daya, rasio umpan - pelarut, dan waktu ekstraksi berturut - turut sebesar $10 \%$, 1:20, dan 10 menit dengan hasil flavonoid sebesar $4,025 \mu \mathrm{g} / \mathrm{g}$. Dengan perolehan nilai rendemen 2,54\% dengan waktu pengawetan optimum 48 jam pada konsentrasi $2 \%$.
\end{abstract}

Kata Kunci: Daun kunyit, flavonoid, microwave assisted exstraction, bioformalin.

\section{PENDAHULUAN}

Tumbuhan kunyit merupakan tanaman tropis yang banyak tumbuh di Benua Asia dengan pemanfaatan sebagai pewarna dan pengharum makanan.Pemanfaatan daun kunyit oleh penduduk hanya sekedar sebagai bahan masakan yang tidak digunakan dalam jumlah besar. Bahkan sebagian besar daun kunyit ini dianggap sebagai limbah dan minim pemanfaatannya (Fitri, 2017). Padahal daun kunyit memiliki senyawa bioaktif flavonoid $(16,89 \mathrm{mg} / \mathrm{kg})$ (Suryana dan Katja, 2009). Senyawa fenolik seperti flavonoid yang terdapat dalam tumbuhan ini mempunyai kemungkinan berperan dalam menentukan sifat-sifat tersebut (Droby dkk., 1998).

Sifat - sifat anti jamur dan anti bakteri ini yang memberikan kemungkinan tumbuhan kunyit dapat digunakan sebagai pengawet makanan. Salah satu bahan pengawet non makanan yang sering digunakan oleh industri kecil adalah formalin. Formalin yang dikenal sebagai pengawet mayat kini banyak disalahgunakan oleh sebagian pedagang makanan cepat saji seperti ; bakso, mie basah, cilok dan lain sebagainya (Faradilla dkk, 2014). Sebagai bahan pengganti formalin maka dapat kita gunakan bioformalin yang aman untuk dipakai dalam mengawetkan makanan. Senyawa flavonoid dan tanin merupakan senyawa yang dapat mencegah perkembangan bakteri pembusuk atau disebut juga antibakteri (Rofik dan Rita, 2012).

Ekstraksi senyawa dari tumbuhan berbantu gelombang mikro lebih efisien jika dibandingkan dengan metode ekstraksi secara konvensional (Routray dan Orsat, 2012). Adapun faktor - faktor yang mempengaruhi hasil ekstraksi dengan berbantu gelombang mikro adalah (i) pelarut; (ii) daya microwave dan suhu ; (iii) waktu ekstraksi ; (iv) sifat matrik tumbuhan dan (v) pengadukan (Chan dkk, 2011).

Penelitian ini bertujuan untuk menganalisa pengaruh variabel daya, rasio umpan - pelarut dan waktu terhadap konsentrasi flavonoid pada tumbuhan Curcuma Longa $L$ dengan berbantu gelombang mikro. 


\section{METODOLOGI}

\subsection{Alat}

MAE, Spektrofotometri UV-VIS, ayakan 80 mesh, gelas beaker, gelas ukur, labu alas bulat, labu ukur, erlenmeyer, timbangan, kertas saring dan corong saring, blender.

\subsection{Bahan}

Bubuk daun kunyit, pelarut aquabidest, ekstrak daun kunyit, $\mathrm{ALCl}_{3}, \mathrm{NaOH} 1 \mathrm{M}, \mathrm{NaNO}_{2}$ dan quercetin.

\subsection{Prosedur Percobaan}

\subsubsection{Persiapan Bahan dan Alat}

Daun kunyit yang digunakan ini dibuat dengan serangkaian proses seperti pengeringan, pengecilan ukuran menggunakan blender dan diayak dengan ayakan 80 mesh.

\subsubsection{Ekstraksi}

Mengekstrak simplisia daun kunyit menggunakan MAE dengan pelarut aquabides dan dibagi menjadi 3 tahap untuk mencari variabel terbaik

a. Mencari daya terbaik dengan variabel $10 \%$, $30 \%$ dan $50 \%$ dari daya maksimum microwave yaitu 399 watt dan dengan waktu 10 menit, setelah itu disaring dan diambil filtratnya.

b. Mencari rasio umpan - pelarut terbaik dengan variabel 1:10, 1:20 dan 1:30 dengan daya $10 \%$ dan waktu 10 menit setelah itu disaring dan diambil filtratnya.

c. Mencari waktu terbaik dengan variabel 10 , 20, dan 30 menit dengan daya $10 \%$ dan waktu 10 menit setelah itu disaring dan diambil filratnya.

\subsubsection{Membuat lauran standar}

Membuat larutan quercetin dengan variabel $2,5,8,10,12,15 \mathrm{mg} / \mathrm{L}$. Mengukur absorbansi semua variabel dengan Spektrofotometri UV-Vis pada panjang gelombang $410 \mathrm{~nm}$.

\subsubsection{Analisa Flavonoid}

$0.25 \mathrm{~mL}$ dari sampel $(1 \mathrm{mg} / \mathrm{mL})$ ditambahkan $1 \mathrm{ml}$ aquabides. Lalu $0,075 \mathrm{~mL}$ $5 \% \mathrm{NaNO} 2,0,075 \mathrm{~mL} 10 \% \mathrm{AlCl} 3$ dan $0,5 \mathrm{~mL}$ $1 \mathrm{M} \mathrm{NaOH}$ ditambahkan pada menit ke 0,5 dan 6. Lalu tambahkan aquabides hingga total larutan 2,5 ml. Larutan di absorbasi pada panjang gelombang $410 \mathrm{~nm}$.

\subsubsection{Penentuan Waktu Simpan terbaik dengan Uji Organoleptik}

Uji organoleptik meliputi aroma, tekstur, dan warna dengan menggunakan 5 panelis pada rentang waktu 24 jam, 48 jam dan 72 jam. Uji Organoleptik dilakukan dengan menggunakan "Skala Hedonik" menurut Olivia,2013. Sampel disajikan secara acak, kepada panelis diminta untuk memberikan nilai menurut tingkat kesukaan.

Jumlah skala yang digunakan terdiri dari 5 skala yaitu :

1. Sangat tidak suka

2. Tidak suka

3. Netral

4. Suka

5. Sangat Suka

\subsubsection{Pencarian Rendemen}

Pencarian nilai rendemen dengan melakukan pemekatan terhadap larutan bioformalin menggunakan Rotary Evaporator sehingga didapat cairan yg kental. Kemudian dilakukan pengurangan kadar air dengan dioven sampai berat konstan.

\section{HASIL DAN PEMBAHASAN \\ 3.1.Pengaruh Daya Alat Microwave}

Percobaan menggunakan variabel daya 10 $\%$ 30\% dan 50\% dengan rasio umpan - pelarut sebesar 1:10 dan waktu ekstraksi 10 menit. Hasil kadar flavonoid menggunakan Spektofotometri UV- VIS dapat dilihat pada tabel 3.1

Tabel 3.1 Pengaruh daya alat microwave

\begin{tabular}{lcccc}
\hline No. & $\begin{array}{c}\text { Daya } \\
(\%)\end{array}$ & Ratio & $\begin{array}{c}\text { Waktu } \\
(\mathbf{m e n i t})\end{array}$ & $\begin{array}{c}\text { Konsentrasi } \\
\text { flavonoid } \\
(\boldsymbol{\mu g} / \mathbf{g})\end{array}$ \\
\hline 1. & 10 & $1: 10$ & 10 & 2,139 \\
\hline 2. & 30 & $1: 10$ & 10 & 1,961 \\
\hline 3. & 50 & $1: 10$ & 10 & 1,784 \\
\hline
\end{tabular}

Berdasarkan Tabel 3.1 menunjukkan bahwa konsentrasi flavonoid akan menurun seiring dengan kenaikan daya yang di pergunakan. Konsentrasi maksimum diperoleh pada penggunaan daya sebesar $10 \%$ dari daya maksimum 399 watt dengan konsentrasi flavonoid sebesar $2,139 \mu \mathrm{g} / \mathrm{g}$. Pada penggunaan daya di atas $10 \%$ menghasilkan konsentrasi flavonoid yang semakin menurun. Dimana kenaikan daya akan meningkatkan energi gelombang mikro pada biomolekul.

Hal ini terjadi dikarenakan adanya konduksi ionik dan rotasi dipol yang menghasilkan tenaga disipasi dalam solven dan bahan tumbuhan sehingga menghasilkan gerakan dan pemanasan molekuler (Gfrere dan 
Lankmayr,2005). Serta Pemanasan yang berlebih akan menyebabkan sel terdegradasi, sehingga aktivitas antioksidan akan menurun (Khairunisa, 2018).

\subsection{Pengaruh Rasio Umpan - Pelarut}

Percobaan ini menggunakan variabel rasio umpan - pelarut 1:10, 1:20, dan 1:30 dengan daya $10 \%$ dan waktu ekstraksi 10 menit. Hasilnya disajikan pada tabel 3.2

Tabel 3.2 Pengaruh rasio umpan - pelarut

\begin{tabular}{ccccc}
\hline No. & Ratio & $\begin{array}{c}\text { Daya } \\
(\boldsymbol{\%})\end{array}$ & $\begin{array}{c}\text { Waktu } \\
(\mathbf{m e n i t})\end{array}$ & $\begin{array}{c}\text { Konsentrasi } \\
\text { flavonoid } \\
(\boldsymbol{\mu g} / \mathbf{g})\end{array}$ \\
\hline 1. & $1: 10$ & 10 & 10 & 2,223 \\
\hline 2. & $1: 20$ & 10 & 10 & 3,673 \\
\hline 3. & $1: 30$ & 10 & 10 & 3,369 \\
\hline
\end{tabular}

Rasio umpan - pelarut berpengaruh terhadap hasil ekstraksi flavonoid dimana semakin besar rasio umpan - pelarut maka konsentrasi flavonoid juga semakin tinggi namun hanya sampai pada titik tertentu. Hasil maksimum diperoleh pada rasio umpan pelarut 1:20. Pada dasarnya rasio umpan pelarut yang lebih besar akan mengakibatkan gradien konsentrasi semakin besar selama proses difusi dari padatan ke larutan sehingga meningkatkan yield ekstraksi. Namun semakin banyak pelarut yang digunakan, kandungan flavonoid yang terekstrak semakin rendah.

Hal ini disebabkan karena volume pelarut yang berlebih dapat menyebabkan gelombang mikro yang dipaparkan akan terkonsentrasi pada pelarut. Akibatnya, efektivitas gelombang mikro dalam memecah sel dan mengeluarkan flavonoid dari dalam bahan menjadi semakin berkurang sehingga total flavonoid yang terekstrak semakin sedikit (Dewi, dkk 2018). Sedangkan jumlah pelarut yang lebih sedikit serta karena adanya penguapan pelarut selama proses ekstraksi, sehingga dapat menyebabkan jumlah analit yang dapat terekstrak menjadi lebih rendah.

\subsection{Pengaruh Waktu Ekstraksi}

Percobaan ini dilakukan dengan variabel waktu ekstraksi 10, 20, dan 30 menit dengan rasio umpan - pelarut 1 : 20 dengan daya $10 \%$. Hasil percobaan disajikan pada tabel 3.3
Tabel 3.3 Pengaruh waktu ekstraksi

\begin{tabular}{ccccc}
\hline No. & $\begin{array}{c}\text { Waktu } \\
(\mathbf{m e n i t})\end{array}$ & $\begin{array}{c}\text { Daya } \\
(\boldsymbol{\%})\end{array}$ & Ratio & $\begin{array}{c}\text { Konsentrasi } \\
\text { flavonoid } \\
(\boldsymbol{\mu g} / \mathbf{g})\end{array}$ \\
\hline 1. & 10 & 10 & $1: 20$ & 4,025 \\
2. & 20 & 10 & $1: 20$ & 3,566 \\
3. & 30 & 10 & $1: 20$ & 3,061 \\
\hline
\end{tabular}

Berdasarkan tabel 3.3 menunjukan hasil konsentrasi flavonoid menurun seiring dengan penambahan waktu ektraksi. Dimana diperoleh waktu ekstraksi maksimum pada 10 menit

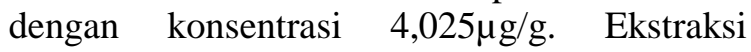
berbantu gelombang mikro ini merupakan proses yang relatif singkat. Energi akan dipindahkan secara efisien ke dalam bahan melalui interaksi molekuler dibawah medan magnet sehingga menyebabkan perpindahan yang cepat pada pelarut ekstraksi dan bahan tumbuhan. Waktu yang lama dapat mengakibatkan degradasi flavonoid yang akan menurunkan konsentrasi atau yield percobaan (Huang dkk., 2017)

\subsection{Rendemen Eksraksi Flavonoid}

Perhitungan rendemen dihitung menggunakan sampel dengan varibel daya, waktu, dan rasio umpan - pelarut terbaik yaitu 10\%, 10 menit dan 1:20. Diperoleh Rendemen dengan nilai $2,54 \%$. Penentuan rendemen untuk mengetahui kadar metabolit sekunder yang terbawa oleh pelarut namun tidak dapat menentukan jenis senyawa yang terbawa oleh pelarut (Ahmad dkk., 2015). Dari hasil rendemen tersebut, dimungkinkan semua jenis metabolit sekunder yang ada pada daun kunyit ikut terbawa misalnya flavonoid, tanin, fenolik, steroida, dan terpenoida (Kusbiantoro, 2018).

\subsection{Uji Organoleptik}

Hasil analisis aroma, tekstur dan warna pada bakso ayam disajikan pada gambar dibawah berikut : 


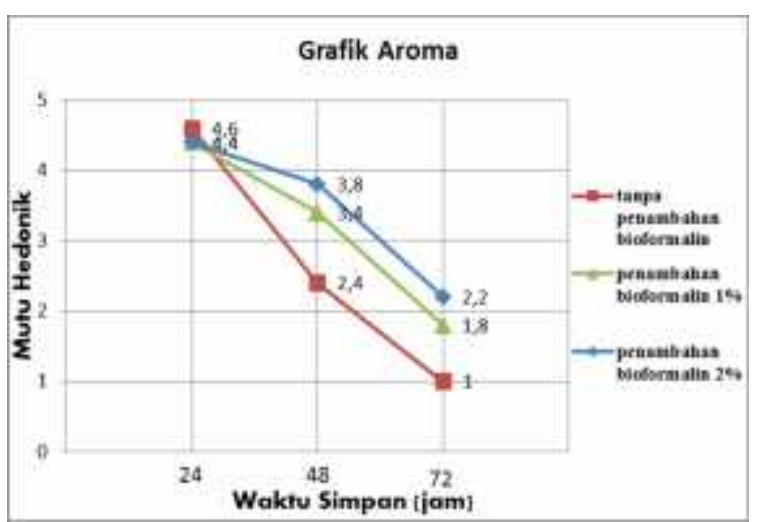

Gambar 3.1 Gambar grafik aroma bakso ayam

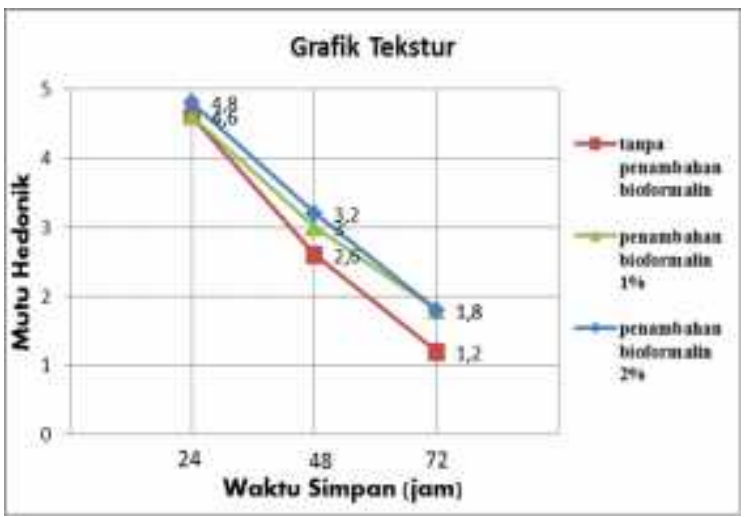

Gambar 3.2 Gambar grafik tekstur bakso ayam

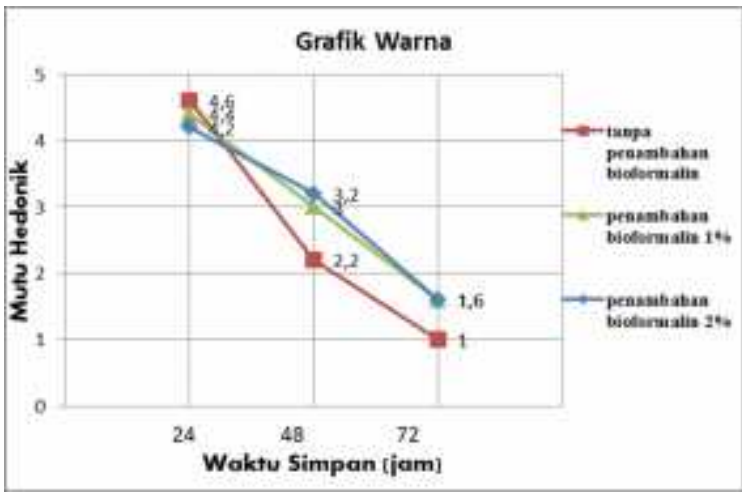

Gambar 3.3. Gambar grafik warna bakso ayam

Dari ketiga gambar diatas menunjukan bahwa semua variabel mengalami penurunan nilai mutu hedonik seiring dengan bertambahnya waktu simpan bakso ayam. berdasarkan Gambar 3.1, untuk aroma bakso ayam tanpa penambahan bioformalin sudah mengeluarkan bau pada waktu simpan 48 jam dan berbau busuk pada 72 jam. Sedangkan pada bakso dengan bioformalin mengeluarkan bau tidak sedap pada waktu simpan 72 jam namun belum mengeluarkan bau busuk dan mendapatkan nilai hedonik sebesar 2,2. Untuk uji tekstur, pada gambar 3.2, dapatdilihatbakso tanpa penambahan bioformalin sudah mengeluarkan lendir pada waktu simpan 48 jam.

Sedangkan pada bakso dengan penambahan bioformalin terdapat lendir pada waktu 72 jam dengan jumlah lendir lebih banyak pada bakso dengan penambahan $1 \%$. Untuk uji warna pada bakso ayam,darigambar 3.3 dapatdilihatbahwa bakso tanpa penambahan bioformalin mengalami perubahan warna pada waktu simpan 24 jam , sama dengan bakso dengan penambahan bioformalin yaitu menjadi abu abu muda. Pada waktu simpan 72 jam bakso dengan penambahan bioformalin memiliki warna orange kecoklatan.

\section{KESIMPULAN}

Dari hasil penelitian ini dapat disimpulkan bahwa variabel daya, rasio umpan - pelarut dan waktu ekstraksi berpengaruh terhadap konsentrasi flavonoid pada proses ekstraksi dengan bantuan gelombang mikro. Perolehan konsentrasi terbaik terdapat pada variabel daya, rasio umpan - pelarut dan waktu ekstraksi berturut - turut sebesar 10\%, 1:20 dan 10 menit dengan jumlah flavonoid 4,025 $\mu \mathrm{g} / \mathrm{g}$. Rendemen yang diperoleh adalah $2,54 \%$. Dengan waktu pengawetan optimum adalah 48 jam pada suhu ruang.

\section{DAFTAR PUSTAKA}

Ahmad, A.R., Juwita., Ratulangi, S.A.D., dan Malik, A., 2015, Pharm Sci Res, Penetapan Kadar Fenolik dan Flavanoid Total Ekstrak Metanol Buah dan daun Patikala (Etlingera elatior (Jack) R.M.SM), 2 (1) : 1-10.

Chan C. H., Yusoff R., Ngoha G. C., , Kung F. W.L, (2011), Microwave-assisted extractions of active ingredients from plants, Journal of Chromatography , 1218 (2011) 6213-6225

Droby S., Cohen L., Daus A., Weiss B., Horev B., Chalutz E., Katz H.,, Keren Tzur M.,, Shachnai A.,(1998), Commercial Testing of Aspire: A Yeast Preparation for the Biological Control of Postharvest Decay of Citrus, Biological Control, 12:2, pp. 97-101

Faradilla.,Yustini A., Elmatris., 2014, Identifikasi Formalin Pada Bakso yang dijual beberapa tempat di kota, Fakultas 
kedoktera, Universitas Andalas. Sumatra Barat.

Fitri, 2013, Pengaruh Marinasi Ekstrak Daun Kunyit (Curcuma Domestica Val) Terhadap Kadar Air, Nilai Ph, Kadar Lemak Dan Kadar Protein Daging Itik, Fakultas Peternakan Dan Pertanian, Universitas Diponegoro, Semarang.

Gfrere, M., Lankmayr, E., 2015, Screening, optimization and validation of microwave assisted extraction for the determination of persistent organochlorine pesticides, Analytica Chimica Acta 533(2):203-211

Huang , J., He, W., Yan, C., Du, X., and Shi, X., (2017), Microwave assisted extraction of flavonoids from pomegranate peel and its antioxidant activity, BIO Web of Conferences 8 , 03008

Khairunisa, 2018, The Effects Of Microwave Extraction Method On The Caratenoid And Antioxidants In Pumpkin (Cucurbita Moschata) Seed, Program Studi Teknologi Pangan,Fakultas Teknologi Pertanian, Universitas Katolik Soegijapranata, Semarang.

Kurniasari., Darmanto., 2017, Ekstraksi Berbantu Gelombang Mikro Pada Oleoresin Kayu Manis dengan Solvent Etanol dan 2-Propanol, Fakultas Teknik, Universitas Wahid Hasyim, Semarang.

Rofik S., Rita D.R, 2012, Ekstrak Daun ApiApi (Avicennia Marina) Untuk Pembuatan Bioformalin Sebagai Antibakteri Ikan Segar, Teknik Kimia, Universitas Wahid Hasyim, Semarang.

Routray, W., Orsat, V., 2012, Microwaveassisted Extraction of Flavonoids: a review

Suryanto Dan Katja, 2009, Aktivitas Penangkal Radikal Bebas Dan Penstabil Oksigen Singlet Dari Ekstrak Daun Kunyit (Curcuma Domestica Val.), Jurusan Kimia, Fakultas Matematika Dan Ilmu Pengetahuan Alam, Universitas Sam Ratulangi, Manado. 